\title{
Preventing within household transmission of Covid-19: is the provision of accommodation to support self-isolation feasible and acceptable?
}

\author{
Sarah Denford ${ }^{1,2^{*}}$ (D) Kate Morton ${ }^{3}$, Jeremy Horwood ${ }^{1}$, Rachel de Garang ${ }^{4}$ and Lucy Yardley ${ }^{1,2,3}$
}

\begin{abstract}
Background: Within-household transmission of Covid-19 is responsible for a significant number of infections. Efforts to protect at risk communities are needed. This study explored the acceptability of offering accommodation to support self-isolation among at risk populations, to prevent transmission of Covid-19 within vulnerable households.

Methods: Mixed methods design structured in two phases. Phase 1: Survey of 545 individuals who had provided consent to be contacted about ongoing research projects into infection control. Phase 2: Semi-structured interviews with 19 participants from ethnic minority and low income communities.

Results: Many survey and interview participants viewed the provision of accommodation as important and necessary in certain contexts. Of the 110 survey respondents, 85 (77\%) said that they were not able to isolate at home. Among this group, 24 (28\%) said they would accept accommodation and 23 (27\%) said that they would probably accept. Of those unable to isolate at home, and at high risk if they caught the virus $(N=36)$ or living with someone at high risk (N 18), 19 (35\%) said that they would accept, and 12 (22\%) said they would probably accept accommodation.

Factors influencing uptake of accommodation included perceived 1) household vulnerability 2) virus exposure and 3) lack of isolation at home options. Barriers to accepting the accommodation offer included 1) able to isolate at home 2) wanting to be with family 3) caring responsibilities 4) mental wellbeing concerns 5) concerns about moving when ill and 6) infection control concerns. Participants raised issues that should be addressed before accommodation is offered, including questions regarding who should use temporary accommodation and when, and how infection control in temporary accommodation would be managed.
\end{abstract}

\footnotetext{
* Correspondence: Sarah.denford@bristol.ac.uk

${ }^{1}$ Population Health Sciences, Bristol Medical School, University of Bristol,

Bristol, UK

${ }^{2}$ School of Psychological Science, University of Bristol, Bristol, UK

Full list of author information is available at the end of the article
}

(c) The Author(s). 2021 Open Access This article is licensed under a Creative Commons Attribution 4.0 International License, which permits use, sharing, adaptation, distribution and reproduction in any medium or format, as long as you give appropriate credit to the original author(s) and the source, provide a link to the Creative Commons licence, and indicate if changes were made. The images or other third party material in this article are included in the article's Creative Commons licence, unless indicated otherwise in a credit line to the material. If material is not included in the article's Creative Commons licence and your intended use is not permitted by statutory regulation or exceeds the permitted use, you will need to obtain permission directly from the copyright holder. To view a copy of this licence, visit http://creativecommons.org/licenses/by/4.0/. The Creative Commons Public Domain Dedication waiver (http://creativecommons.org/publicdomain/zero/1.0/) applies to the data made available in this article, unless otherwise stated in a credit line to the data. 
Conclusion: The provision of accommodation to prevent within household transmission of Covid-19 is viewed as acceptable, feasible and necessary by some people who are concerned about infection transmission in the home and are unable to self-isolate or socially distance at home. Different households will have different requirements, e.g., those with caring responsibilities, and to overcome these challenges additional support may be needed for the provision of accommodation to be feasible to those who could benefit most.

Keywords: Covid-19, Self-isolation, Quarantine, Infection control, Participatory research

\section{Background}

Human behaviour is central to the transmission of Covid-19. To reduce transmission, a series of behavioural interventions were suggested and implemented [1]. Whilst the introduction of social distancing behaviours can reduce the spread of Covid-19 within the community [2], people with symptoms of the virus are instructed to remain in the home; potentially with cohabiting families and friends. This has led to clusters of infection within households [3], and within household transmission being highlighted as a dominant route of infection [4, 5]. In order to avoid within household transmission of Covid-19, excellent infection control measures are needed [4]. This includes introducing hygiene protocols, appropriate use of personal protective equipment (e.g., face mask use when necessary), and within household distancing and segregation - or 'selfisolation' - of infected individuals [5-7]. Although effective for reducing within household transmission [2, 8], there is substantial variation in the extent to which the public are able and willing to adhere to these behavioural solutions [9-11].

Innovative solutions to prevent the spread of the virus within households should be considered.

One potential solution to preventing the transmission of the virus within the home is isolation outside the home. Centralised - as opposed to individual - isolation has been suggested [3] and implemented successfully in locations such as China and Korea [12]. In Wuhan, for example, existing public venues were rapidly converted into what are termed 'Fangcang shelter hospitals'. Individuals with symptoms of Covid-19 would isolate within these shelters, away from friends and family. In addition to providing food and medical care, these locations ensured adherence to self-isolation guidance, keeping the families and household members of the infected individual safe from infection, and provided social engagement, reducing psychological distress associated with selfisolation [13]. Indeed, a key difference between Fangcang shelters and makeshift or emergency hospitals is the social space provided, allowing residents to engage and socialise with others during the isolation period [13]. However, although cost effective and acceptable to residents living in Wuhan, the substantial differences in culture and living conditions mean that Fangcang style accommodation may be less likely to be accepted by individuals in many European countries.

A small number of European countries have converted some hotels, hostels, dormitories or specialised facilities into special facilities to accommodate people who are experiencing symptoms of the virus [14]. This strategy has not been widely implemented, and most of Europe and the United States continue to encourage individuals with symptoms to self-isolate within the home. In the United Kingdom, National Health Service (NHS) workers were offered, on a voluntary basis, the option of staying in NHS reimbursed hotel accommodation to enable them to continue to work if they were living with others who may be vulnerable. For those who can afford it, self-funded luxury hotel "quarantine packages" are available [15-17], but, funded accommodation has not yet been offered in the UK to individuals or communities outside the NHS, who may be at risk.

Whilst the offer of funded accommodation within which to self-isolate or quarantine is a potentially viable strategy, it is critical that interventions are culturally appropriate and acceptable to the communities that they serve to protect. This requires extensive input from target users to understand the environmental and cultural context within which the intervention could be introduced, as well as the psychological and social factors likely to influence uptake [9]. In particular, we were keen to explore participants' views about how the initiative could work in practice; for example, whether the person with Covid-19 should be offered accommodation or the vulnerable members of the household.

The aim of this research is therefore to understand whether or not offers of accommodation would be acceptable and feasible for people concerned about reducing infection transmission in the home, to elicit discussions regarding how this scheme could work in practice, and explore what we can do to improve advice and approaches to reduce transmission of the virus within the home.

\section{Methods}

\section{Study design}

Our study used a mixed methods design structured in two phases. In phase 1 , we conducted a survey study of a sample of volunteers from our existing database of 545 
individuals who had been recruited through their engagement with Germ Defence, a website aiming to reduce infection risks in the home (Supplementary file 1). These individuals had provided consent to be contacted about ongoing research projects. In phase 2, we conducted semi-structured interviews with 19 participants from ethnic minority and low income communities. These interviews were designed to help us explore further concepts identified in phase 1 , and to elicit discussions regarding how accommodation could best be utilised.

\section{Phase 1}

\section{Data collection}

Volunteers who had previously provided consent to be contacted and invited to take part in research were recruited via email distribution lists between June and July 2020. Participants were invited to complete a confidential online survey regarding their ability and willingness to isolate within the home, and the acceptability of accommodation to isolate outside the home. Informed consent was collected online before starting the survey.

\section{Data analysis}

Frequencies and descriptive statistics are presented for closed survey questions. Free text answers were used to offer further insight into, and explanations for, answers given to closed survey questions. We identified barriers and facilitators related to the provision of accommodation with qualitative content analysis in three stages [18, 19]. First, responses to the survey were coded by two authors independently. During stage two, codes were categorised into a unique list of barriers and facilitators, which were discussed and refined by the same two authors. Data were then assigned to each category, and counts of text assigned to each category were generated.

\section{Phase 2}

\section{Data collection}

Volunteers were recruited via existing contacts with community groups, social media advertisements, and snowball sampling. We targeted individuals from ethnic minority and low income groups because data have shown that those from ethnic minority communities have a markedly higher risk of infection [20, 21] and worse clinical outcomes, including intensive therapy unit admission and mortality [22, 23]. Likewise, those living in the most deprived areas are more likely to be diagnosed with Covid-19, and have worse outcomes than those living in the least deprived areas [23]. The reasons underpinning the disproportionate impact of the virus on these populations are multiple and complex, but include increased risk of occupational and geographical exposure [21, 23-25] paired with reduced opportunities for social distancing and self-isolation [9]. Interested individuals responded to an invitation to take part in research to understand experiences and interpretations of self-isolation and protection during the pandemic. Participants were over the age of 18 years and residing in the UK. We purposely sampled for diversity in key factors, including ethnicity, living arrangements, occupation, and vulnerability. Sample size was informed by the concept of 'information power', [26] with analysis and sampling conducted in parallel and continuous assessment of the suitability of the information within the sample with regard to study objectives.

Potential participants contacting the research team were provided with a study information sheet and given an opportunity to ask any questions. Participants were informed of the voluntary nature of participation in the study, and assured of the confidentiality of the data collected. Interviews were conducted throughout June and July 2020 by the lead author who is a trained qualitative researcher. As all interviews were conducted via the telephone or online, audio recorded (rather than written) verbal consent was obtained.

The semi-structured topic guide (Supplementary file 2) was informed by data collected during phase 1 as well as existing literature, and conversations with experts in public health, behaviour change and intervention development. Questions were designed to explore participants' current living situation, their experiences of isolation within the home, perceptions relating to the provision of accommodation to reduce transmission in the home, and suggestions regarding how accommodation may be used and facilitated. The topic guide was deliberately flexible enough to allow participants to consider and discuss both the option of accommodation being offered to the person with Covid-19, or the household contacts, and to discuss the pros and cons of each.

\section{Analysis}

Data from the interviews were analysed using a thematic approach aimed at identifying issues raised by the participants and ways in which these issues may be mitigated [27]. Following the stages of thematic analysis, two researchers independently read transcripts to assign codes to the data and identify possible themes. These themes were discussed and refined through discussion. An initial framework was developed, checked against the data, and refined as necessary. Charts were developed for each theme in the framework, and relevant text from the transcripts were be copied or summarised under each theme in the chart. Charts were then used to compare data within and between individuals. Participants were invited to discuss the analysis and interpretations with the researchers via skype or email. 


\section{Results}

Phase 1

A total of 110 respondents (20\% of those invited) completed the survey (Table 1), 96\% were over the age of 41 years and $94 \%$ were white. The distribution of age ranges and level of education amongst survey respondents were similar to the distributions amongst those who were invited but not complete the survey. A similar proportion (approximately 20\%) of survey respondents and non respondents lived with someone at increased risk.

Of all respondents, 24 (22\%) stated that they would accept an offer of accommodation if it was available, 25 (22\%) said that they would probably accept, 21 (19\%) said they would probably not accept and 39 (35\%) said that they would not accept. Of the $85(77 \%)$ participants who said they were not able to isolate at home, 24 (28\%)

Table 1 Participant characteristics

\begin{tabular}{|c|c|c|}
\hline & $\begin{array}{l}\text { Phase } 1 \\
(N=110)\end{array}$ & $\begin{array}{l}\text { Phase } 2 \\
(N=19)\end{array}$ \\
\hline \multicolumn{3}{|l|}{ Age } \\
\hline $18-25$ & 0 & $2(10 \%)$ \\
\hline $26-40$ & $2(2 \%)$ & $8(42 \%)$ \\
\hline $41-60$ & $35(32 \%)$ & $8(42 \%)$ \\
\hline $61-70$ & $41(37 \%)$ & $1(5 \%)$ \\
\hline Over 70 & $30(27 \%)$ & 0 \\
\hline Missing & $2(2 \%)$ & 0 \\
\hline \multicolumn{3}{|l|}{ Sex } \\
\hline Male & Not collected & 7 (37\%) \\
\hline Female & Not collected & $12(63 \%)$ \\
\hline \multicolumn{3}{|l|}{ Ethnic group } \\
\hline White & $104(94 \%)$ & $6(32 \%)$ \\
\hline Mixed / multiple ethnic groups & $1(1 \%)$ & $1(5 \%)$ \\
\hline Asian / Asian British & 0 & $9(47 \%)$ \\
\hline Black / African / Caribbean / Black British & $1(1 \%)$ & $3(16 \%)$ \\
\hline Missing & $4(4 \%)$ & 0 \\
\hline \multicolumn{3}{|l|}{ Leaving full time education } \\
\hline Before finishing school & $1(1 \%)$ & $1(5 \%)$ \\
\hline After finishing school & $42(38 \%)$ & $4(21 \%)$ \\
\hline After finishing university & $36(33 \%)$ & $4(21 \%)$ \\
\hline After postgraduate studies & $28(25 \%)$ & $1(5 \%)$ \\
\hline Missing & $3(3 \%)$ & $9(47 \%)$ \\
\hline \multicolumn{3}{|l|}{ Experience with Covid-19 } \\
\hline I am at increased risk & $48(44 \%)$ & $1(5 \%)$ \\
\hline I live with someone high risk & $19(17 \%)$ & $7(37 \%)$ \\
\hline I have had the virus & $7(6 \%)$ & $1(5 \%)$ \\
\hline I live with someone who had the virus & $1(1 \%)$ & 0 \\
\hline None of the above & $32(29 \%)$ & $10(53 \%)$ \\
\hline Missing & $3(3 \%)$ & 0 \\
\hline
\end{tabular}

said they would accept, 23 (27\%) said that they would probably accept, 18 (21\%) said that they would probably not accept, and 16 (18\%) said they would not accept. Of those unable to isolate at home, and who also considered themselves to be of high risk if they catch the virus

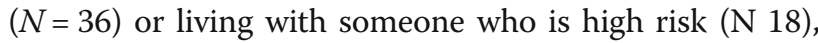
a total of 19 (35\%) said that they would accept, 12 (22\%) would probably accept, 14 (26\%) would probably not accept, and 8 (14\%) would not accept.

Three factors were coded as facilitators influencing decisions to accept an offer of accommodation to reduce transmission in the home (Table 2). These were to protect others within the household, to control the virus, and to avoid using shared spaces. Seven barriers to accepting the offer of accommodation included 1) the ability to isolate within the home, 2) not wanting to be apart from family 3) having caring responsibilities [4] concerns about the impact of isolation on mental wellbeing and relationships [5] concerns about the upheaval of moving when ill, [6] perceived risk of catching or spreading coronavirus if leaving the building, and [7] unfeasible for unspecified reasons 'Table 2'.

\section{Phase 2}

A total of 19 participants took part in the interviews from Black African $(N=2)$, Black British $(N=1)$, Mixed White / Black Caribbean $(N=1)$ Indian $(N=5)$, British Indian $(N=2)$ Asian $(N=1)$ British Asian Pakistani $(N=$ $1)$ and White $(N=6)$ ethnic groups (Table 1$)$. The participants had varied feelings about the acceptability of accommodation outside the home, with most feeling they would accept it if needed or as a last resort, and very few feeling they would be unlikely to accept. One participant had moved a family member out of the home for 11 weeks during the pandemic. Interviews lasted between 21 and $55 \mathrm{~min}$ (mean duration $38 \mathrm{~min}$ ).

\section{Protecting the household}

Participants were positive about the idea of accommodation being offered to reduce transmission of the virus in the home. It was considered to be a highly effective way of preventing the spread of the virus among those who were unable to isolate within their current homes.

"If I was offered accommodation which meant that my family were kept safe, then absolutely I would, I would welcome it" (Participant 14, White, female).

Critically, participants thought that it had the potential to save lives:

"Wow that would probably have saved a lot of lives actually. Yeah" (Participant 03, British Asian Pakistani, male). 
Table 2 Facilitators and barriers to the uptake of accommodation for isolation - results of the content analysis of survey text

\begin{tabular}{|c|c|c|}
\hline & Description & Example quote \\
\hline \multicolumn{3}{|l|}{ Facilitators } \\
\hline $\begin{array}{l}\text { To protect others in my } \\
\text { household/if someone at } \\
\text { home was high risk }\end{array}$ & $\begin{array}{l}\text { Includes both actual and hypothetical comments } \\
\text { about having someone at high risk at home. }\end{array}$ & $\begin{array}{l}\text { If it was a case of protecting my wife, I would probably } \\
\text { leave like a shot if it was to her advantage. }\end{array}$ \\
\hline To control the virus & $\begin{array}{l}\text { Includes broader social sense of doing the right } \\
\text { thing. }\end{array}$ & I would be motivated by the compulsion to save others. \\
\hline To avoid using shared areas & To avoid needing to use shared rooms in the home & $\begin{array}{l}\text { I live in a big enough house to keep apart, but only one } \\
\text { bathroom, so because of shared shower facility might go } \\
\text { elsewhere }\end{array}$ \\
\hline
\end{tabular}

\section{Barriers}

Can self-isolate where I am

Not wanting to be apart from family

Caring for others

Concerns about implications of isolation for mental wellbeing and relationships

Upheaval of moving when ill/want to be in own home when ill

Perceived risk from others in the building

Unfeasible for unspecified reasons

\section{Dependent on:}

Location of accommodation

Facilities available/suitability of accommodation

Support provided for those left at home

Medical care available at accommodation

Access to $\mathrm{Wi}-\mathrm{Fi}$

Hygiene and cleanliness of accommodation

Special dietary needs being met/access to food

Taking my pet with me

How much fun it would be

Whether I have confirmed
Includes having enough space to self-isolate at home, or living alone

Unwilling to be away from family

Having caring responsibilities at home, including children, spouse, parent or pets. Excludes comments where alternative caring options were considered (see below).

Worried about negative impact on mental wellbeing, including loneliness and boredom, or missing family members

Preference for being at home when feeling ill

Concerned about risk of catching the virus from others in self-isolation accommodation

Self-isolation elsewhere is perceived as unfeasible but no reason is given as to why
N

25

We live in the countryside and we are able to self-isolate

I doubt if we could manage apart from each other we are 10 so interdependent on each other.

Someone who is dependant on me. I would not be able to 4 support them in any way if I were somewhere else.

Self-isolating can be lonely without contact with other 4 sere but doing it in your own home is more comforting with your own things around you

Would be better for others to be removed and leave sick person in familiar surroundings

Definitely would not accept accommodation situated in a 2 building designated for multi occupancy or in an area with higher numbers of fatalities or cases.

There are no circumstances in which I could feasibly selfisolate away from home.
Location of accommodation, focused on proximity to it would need to be relatively close by so that, should my home to allow the person both to receive and provide care to those still at home.

Includes requirements for accommodation e.g. comfort, outside space.

Includes considerations about what support would be provided for children, spouses or parents they care for

Consideration of medical care available and who could look after them, either due to Covid-19 or due to other health conditions.

Needing Wi-Fi for staying in touch with people, or running business

Concerned about germs in the self-isolation accommodation

Unsure about how and what food would be provided

Wanting to take a pet into self-isolation accommodation

Considering how much fun it would be

Considering how necessary it is to self-isolate son need care, I could return home as I would not want him to be on his own if he became ill and we have no other support nearby.

Would depend on the quality of the facility - I would not like it to be Spartan, uncomfortable, with poor Wi-Fi, nowhere near a good hospital

It would depend on whether someone else who was not ill 9 would be available to look after my son

I would isolate elsewhere especially if a close watch in a nursing capacity was available for me and other isolation participants

I would want to be able to use my PC, phone and tablet.

I am more confident in the cleaning regime I have at my own home than trusting it to someone else. I would not be comfortable living anywhere that I hadn't cleaned myself to my own high standards.

I would also want vegetarian food, or ability to get vegetarian (ideally vegan) food.

Whether I could take my dog with me

Where it was, what facilities were available, whether l'd be 1 able to get food, and how much fun it would be.

If I had been given a positive CV19 test result and was

1

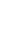


Table 2 Facilitators and barriers to the uptake of accommodation for isolation - results of the content analysis of survey text (Continued)

\begin{tabular}{lll}
\hline & Description & Example quote \\
\hline $\begin{array}{l}\text { Covid-19 or just possible } \\
\text { exposure }\end{array}$ & $\begin{array}{l}\text { depending on whether a confirmed diagnosis of the } \\
\text { virus has been given. }\end{array}$ & $\begin{array}{l}\text { being asked to isolate remotely to protect my family, I } \\
\text { would do so. I would not, however, go into precautionary } \\
\text { remote self-isolation in a setting where CV19 was known } \\
\text { to be present in other residents simply on the basis of sus- } \\
\text { pected contact with a CV19 carrier. }\end{array}$ \\
\hline
\end{tabular}

\section{Risk}

The decision to accept, or not, the offer of accommodation appeared to be influenced by how at risk the person considered themselves or their household to be. Perceived risk was influenced by how vulnerable the participant (or their household) were perceived to be, level of exposure to the virus, and level of contact with household members.

\section{Vulnerability}

Eight participants considered themselves or a member of their household to be vulnerable, and this was strongly influential in decisions regarding the use of temporary accommodation. One participant, whose husband had moved out of family home for 11 weeks over the pandemic, explained how keeping her vulnerable daughter safe was their main priority:

"It's just something that has to be done, you know, and he actually didn't come back inside the house, he left for work that morning and then didn't come back for 11 weeks. His bags were packed, his bags were packed and the hotel was booked by the evening and gone" (Participant 18, White, female).

Participants who did not consider themselves (or their household) to be vulnerable reported that they would be more willing to accept the offer of accommodation outside the home if they or their family were vulnerable:

"Yeah maybe if I had my older relatives with me, or I had somebody who um, you know had any underlying health condition, probably yeah I would have offered to go out, but in the current situation I wouldn't have, so. If I had somebody who was living with me who was over 65 years old or who had heart disease or was diabetic, I would offered to go out yes of the house" (Participant 06, Indian, female).

Due to the severity of the virus, any one could consider themselves to be vulnerable, regardless of age and health status:

"I even read on the net or so, I'm not sure if this information is credible or not, but still what I saw on the net is even if you get the virus even if you recover from it, it can have detrimental consequences on your health. For example I read somewhere on the net I read that if you have the virus it can damage your lungs, like, forever, it can have impact on your lungs forever, so this bit of information is quite scary" (Participant 07, Indian, female).

\section{Exposure to the virus}

Accommodation was considered to be particularly important for those who are in situations in which there is potential for high exposure to the virus. There was wide understanding that those from ethnic minority and low income communities were more likely to be in situations in which exposure to the virus is probable:

"Lots of people of colour, and not just, Bangladeshi etcetera, who work in jobs where they have no choice but to go in. You know, if someone said isolate, they would say 'well how will I feed my family?' They have to go in. So they're in jobs where they have to go in, they have to mix with the public" (Participant 11, Black African, female).

Participants even described situations in which people from ethnic minority communities were asked to leave accommodation due to increased exposure to the virus:

"When he got back [from work] the door locks were changed and she [the landlady] said 'I'm really sorry but I can't have you in here because I'm too frightened, you're a cab driver, you're seeing all these people you're going to infect the whole house you know, I'm sorry I can't have you in here'” (Participant 11, Black African, female).

Whilst recognising the value of accommodation, those who were not exposed to the virus thought that accommodation would be unnecessary for their household:

"If I'm not taking the precaution for example, if I have to go to work, then yeah I would suggest for him to isolate somewhere else because I might have the virus in transfer it to him, so yeah. But my case is different because I work from home and I'm not going out and I'm not meeting people, so yeah. There would be no point for him to selfisolate somewhere else when I'm not going out" (Participant 07, Indian, female).

\section{Contact with household members}

Accommodation was viewed as being important for those who are unable to isolate from their household due to the size of the house and / or the size of the household. Participants described how they would be willing to move out of the home as the amount of shared space would make isolation within the home difficult: 
"Well personally, I wouldn't have been any choice, I think it's the best way to prevent either him or me from getting the virus because living in the same house, it would be, uh the risk would be very high because we are sharing the same bathroom, the same kitchen, uh you know, so it would be very difficult" (Participant 07, Indian, female).

Among those from ethnic minority communities in particular, this was considered to be a substantial problem as multigenerational households were common:

"That idea was a very good idea. I mean in [home town] there are areas where you have three generations living in a terraced house, grandparents, parents and the children yeah. Okay yeah now the reason why there is such a high rate of the virus here in [home town] is because of the housing here. Yeah outdated housing, and you know, because the family unit is very good, they look after each other, but because of COIVD it's come back to haunt us big time" (Participant 12, Asian, male).

However, even those who had sufficient space for isolation highlighted difficulties in containing the virus and preventing the spread of viruses within the household:

"I think personally that's a really really good idea. Because going back to what I was saying about infection control I know how hard it must be to limit exposure if one of you's got a virus, not just Covid, but any virus" (Participant 14, White, female).

\section{Key concerns}

Participants raised a series of issues and concerns surrounding the provision of accommodation outside the home that should be addressed before such a scheme could be offered. Participants were keen to understand who should use temporary accommodation, at what stage, and for how long. Concerns were also raised among those with caring duties and responsibilities, and questions were asked regarding who would fund the scheme.

\section{Timing and duration}

Participants wanted clarification regarding the stage at which people should move into temporary accommodation, and for how long. Participants were concerned that it would be too late to move out of the home once symptoms had presented.

"It's, the, to me, because all the guidance and information that we've had is that you're contagious before you start showing symptoms, I wouldn't want to, because in my opinion if that is all true, you would already been exposed to it, he'd have already had it or already have it, um it just it feels like that would be too late" (Participant 15, White, female).
Despite concerns about leaving it too late, participants were not willing to move out of the home for long and unspecified periods of time:

"I will be very very reluctant to go and live somewhere else. If it's for about a week or something I don't mind, but uh, but still yes it's just a matter of change because we have always lived in our houses, so to go out and live somewhere else it's quite a bit of a change" (Participant 13, Indian, male).

In the case of the extremely clinically vulnerable, the duration was deemed necessary to protect the family:

"You've just got to get through it, and it was only like, well it could have been 12 weeks, but in a lifetime it's not that long, really" (Participant 18, White, female).

Who should use temporary accommodation?

Participants raised questions about whether the intention would be for symptomatic persons or vulnerable persons to leave the home for temporary accommodation. Concerns were expressed regarding the potential of infected individuals to spread the virus should they leave the home to stay, for example, with a family member:

"I think I would probably self-isolate too at my own house, rather than, because I might already have symptoms unknowingly, and then if I go to another household I might spread it to say, like my mum, so I think I would actually stay put" (Participant 02, Mixed White/ Black Caribbean, female).

In addition, concerns were also raised regarding the potential for those who are not infected to catch the virus in temporary accommodation:

"Again I would kind of feel I would be safer at home... You go into somewhere else that I couldn't guarantee would be as clean as I would you know, me cleaning it" (Participant 17, White, female).

Participants suggested schemes in which exposed workers were asked to move into temporary accommodation as a preventative measure, thus saving infection from entering the household in the first place:

"I think almost, you're better offering it to the workers who might go back, so like, a lot of people still worked throughout, where they couldn't, so actually, were they the ones taking it back into their own homes, so actually would it be better targeting the workers and saying right if this happens again, if you are a key worker and you've got people at home, then you go to the hotel, like the NHS staff did, rather than let's have it for people who are sick" (Participant 19, White, male).

For healthy individuals moving out to protect vulnerable residents, the ability to continue to work was important, and accommodation with internet access and / or within commuting distance of their work site would be necessary: 
"You know, if you were the person who was Covid free and leaving your family in the house, I don't know which way round you suggest because if I was Covid free I'd still want to work, so it would have to be close to work" (Participant 14, White, female).

"If it was me going to self-isolate, for example, um, and I work from home you know, I would want, you know, I would like to be able to still have my internet and be able to carry on with my work" (Participant 01, Black African, female).

\section{Caring responsibilities}

Among those who had caring responsibilities or were dependent on others, concerns were raised as to who would care for the family in their absence:

"Um, it would be hard and difficult because you're used to living with each other you're reliant on each other as a family, you know, I do the shopping for the house most of the time so you know, cooking and things like that, so if I wasn't there, or my husband wasn't there, you know, because of the kids and all that" (Participant 04, Black British, female).

Participants described defined roles and responsibilities for each household member, and removal of key persons was viewed as problematic:

"I'm just wondering now what would have happened if she [participant's wife] had the Covid 19, because she is the main person who drives the house, because she does the cooking and looks after my mum, so if she was made to go out and live somewhere else then my mum would have problems, we would have problems" (Participant 13, Indian, male).

Among ethnic minority communities in particular, the need and desire to care for family members was a considerable cause for concern. Allowing others to care for their relatives was something that was only to be considered as a last resort:

"I wouldn't like to move out from my house, but if it is really essential then I would move, but I would try to fight it off (laughs) yeah, and I guess uh, if it happened to my mum then my mum would be the same, she wouldn't like to live elsewhere, this was her home for the last 40 years. So because, with Indians we are very close knitted families, we tend to stick by each other, so to her it would probably do more damage going away from us than uh, and then uh, yes, than living not here" (Participant 13, Indian, male).

Concerns were raised about having to leave vulnerable members, potentially putting them at increased risk of exposure to the virus:

"If I worked within the NHS and I was a key worker in that respect then possibly, but I still think just would be very difficult for me to leave the family home because of [son's name] and again, husband and his medical condition, because he wouldn't be able to look after my son, our son the way I would like, picking up food and medication and what not, and then he'd have to, if I wasn't there he'd have to take the lift and sort of opening up more risk to, he'd be more in contact with people too, so I would say no in that respect" (Participant 17, White, female).

However, there was recognition that despite best efforts carers may contract the virus and participants had started to make tentative plans for how they would cope should this happen:

"But that was constantly at the back of my mind like, I am going to the shops and say if I caught the virus on the handle of a trolley and then I touch my nose or my eyes and I have caught the virus now and will I have to relocate or move to my bothers house and who would care for my mother? And these were all questions at the back of my mind, but I do know my house is a 4 bedroom house and I could have self-isolate in another room and not put my mother to more risk or more harm... I would go into a separate room in the house and then sleep in the bed and then ideally move, um, not have any contact at all with my mother in the house and call my brother and ask him to intervene" (Participant 05, British Indian, male).

\section{Social and emotional support}

Despite recognising the value and need for accommodation outside the home, participants struggled with the idea of having to leave the family and home:

"If you're forced to stay at home at least you have all of your belongings, all things that bring you comfort and people around you. But if you're in a hotel room by yourself with just the TV and yeah, I would be so bored I think. Probably very anxious as well and quite upset. I'm such an over thinker as well so I would just be overthinking everything. But also at the same time if it meant that my partner doesn't catch it, then I think that's probably the main thing on my mind, if it's temporarily a solution and hopefully that would stop the spread so I would try to look at the positive side of things, but if it was more than two weeks then yeah I really don't know how I would deal with that" (Participant 02, Mixed Whitel Black Caribbean).

It was thought that it would be emotionally challenging to be alone and in unfamiliar surroundings:

"I think that would be quite scary like having to do, like I mean I can't imagine having to do this entire lockdown period by myself, like, obviously I would have to manage but there would have been a lot of different struggles with that kind of thing and I know people who have done it have been lonely and it would have taken a while to adapt, it would be really difficult" (Participant 10, Asian British, female). 
Participants highlighted the need for facilities to enable them to continue to communicate with their friends and family throughout:

"I have a lot of, all my social stuff is now online, so my theatre group, we rehearse online, we have various support groups and stuff, so for me it would be very important to still be able to have that" (Participant 01, Black African, female).

\section{Essential requirements}

Whilst all participants reported requiring only the basics, further detail regarding food, washing and cleaning facilities were needed:

"I think a room with internet, and uh a bathroom and then just an understanding of how the uh meal system will work" (Participant 08, Indian, male).

\section{Food in particular was a key concern}

"Um, to be able to cook my own food, for me food is very important to me, it is to everybody, but not everyone has the kind of attention to what they eat, I don't eat meat, um, so um, you know, I eat fish but I, yeah I like to have my own space to cook my food" (Participant 01, Black African, female).

Indeed, there were reports of food related complaints from other locations within which this system is widely implemented:

"Well in the beginning they [residents in isolation facilities in [country]] were really complaining about the food that they were getting in the centres ... and yeah after one or three weeks, I mean, I guess maybe they changed the types of food they were getting" (Participant 07, Indian, female).

Those who had used accommodation to avoid transmitting the virus to vulnerable members of the household described how they had had to work hard to ensure food and cooking facilities were available:

"He had local chip shops offering to cook him food, especially in the early days when we didn't really know, we hadn't really found our routine, so like the local fish and chip shop were feeding him, to be fair the people who run the hotel were feeding him, because they live on site, he had work colleagues bringing him plates of food, people dropping him food off, and then we kind of found routine, somebody gave him a microwave, somebody else gave him a fridge, somebody else gave him a toaster. It was a real community effort. Yeah after about 3 or 4 weeks he fell into a routine and he could cook himself stuff so it wasn't so bad" (Participant 18, White, female).

Those in temporary accommodation could also provide tangible support for vulnerable members of the family at home:
"So for that rocky stage when people were struggling [to secure priority slots], yeah I had a little servant on the outside" (Participant 18, White, female).

Participants also described a need for outside space to maintain physical and emotional health:

"I'd need to be able to get outside, to have, like here I have a garden here, so it's just to be able to, you know, even when it's raining I walk out to the garden just to get some air" (Participant 01, Black African, female).

Indeed, outside space for physical activity was considered invaluable to those who had moved out of the home:

"He runs. A lot. An awful lot. So yeah that is how he coped. Yeah, and like initially we thought it was going to be a lot harder the lockdown, so the first week he thought I'm just going to run when I can because we thought exercise was going to be stopped. So he kind of hit the 50 mile a week mark, and then it didn't stop, so he just kept that up really. Just running every day" (Participant 18, White female).

\section{Funding}

Participants were concerned about costs associated with temporary accommodation. Participants were unable to cover the costs themselves, and the one participant whose husband had used accommodation to prevent transmission of the virus to her vulnerable daughter described how it was only possible because it was free of charge. Although the costs were later covered by the National Health Service (NHS), she described how it would not have been possible to pay for accommodation without the goodwill of the community:

"He was really lucky because I know a lot of NHS workers had to wait to move out because NHS trusts and health boards took a while to get their system working, but one of the local hotels, because we live in quite a small area, one of the local hotels offered free rooms, so he was actually able to move out straight away, on that very first Monday he was out. So, yeah. And the health board did pay in the end, but it was right at the end that they decided they were going to pay for it, but the hotel would have given him free room for like 10 weeks, 10, 11 weeks" (Participant 18, White, female).

Despite the lifesaving potential of the scheme, many were unconvinced that it would be funded by the current government:

"I mean, in all honesty I would be like incredibly surprised if um that was like, if this current government were offering that to people" (Participant 03, British Asian/ Pakistani).

"Yeah. So that is a very splendid idea if that was possible, but economically it's not viable is it? It's a good option but economically I don't think this government would go for it anyway. But yeah it's a very good system 
that if it was in place. Yeah." (Participant 12, Asian, male).

\section{Discussion}

\section{Summary of findings}

To our knowledge, this is the first study to have explored issues surrounding the option of accommodation to prevent transmission of the virus in vulnerable households. This work reveals that the offer of accommodation to protect vulnerable households is viewed positively by some people who feel their household is at risk. Data collected from both survey and interview participants highlighted concerns regarding the spread of the virus within the household, and a need for solutions to prevent this. Interviews provided insight into populations who would be likely to accept and benefit from the offer; and it was suggested that those who are vulnerable, are likely to be exposed to the virus, and who are unable to isolate within the home would benefit most. Participants who met one or more of these criteria appeared very willing to accept the offer of accommodation compared with those who consider themselves or their household not to be vulnerable, were not employed in public facing occupations, and/or had capacity to isolate within the home. Crucially, and in line with existing research [20], those from ethnic minority and low income communities were considered to be more exposed and less able to isolate than those from high income backgrounds.

Participants questioned who should use temporary accommodation and at what stage, with legitimate concerns being raised regarding the utility of isolating outside the home once symptoms are present. In locations in which accommodation has successfully been used to support self-isolation outside the home, it is often the symptomatic persons who are offered accommodation for isolation [13, 14]. In the UK, NHS staff who are living with vulnerable family members have been offered accommodation to protect the family whilst allowing those not at high risk to continue to work [28]. Our study suggests that both approaches could be feasible and acceptable to high risk audiences, but the offer of accommodation must be timely, and appropriate infection control measures must be in place. Different households will have different requirements - there is no 'one size fits all'. However, as lockdown restrictions are lifted, and test, trace and isolate becomes a key strategy in controlling the virus, making support available to allow certain individuals to isolate safely could make a potentially valuable contribution to reducing transmission, morbidity and mortality.

\section{Implications of this study}

This study revealed some important issues that would need to be addressed to ensure the acceptability and feasibility of any offer of accommodation for those who need it. Drawing together findings from the survey and interviews we consider below some of the options available, key concerns associated with isolating outside the home, and ways in which these may be mitigated.

In locations in which accommodation is provided, it is the individual with the virus who would isolate outside the home in order to protect vulnerable household members [14]. Participants were concerned that, by the time symptoms were evident, transmission of the virus to other household members would already have occurred. However, with a test, trace and isolate system firmly in place, it would be possible for those who have been in contact with virus to be offered accommodation to quarantine before symptoms emerge. Indeed, individuals who are informed that they have been in contact with the virus may not be willing to return to their homes to await test results if they are living with vulnerable relatives. The offer of accommodation for individuals in this situation could be highly effective.

A second option for utilising accommodation to prevent transmission of the virus within the household involves moving vulnerable people out of the home should household members become symptomatic. Although this was seen as a viable option, again, there were concerns that it would be too late to make use of temporary accommodation at the stage at which infected persons are showing symptoms. There is however, emerging evidence to suggest that viral load is associated with disease severity [29], and initial viral load is likely to be a contributing factor [30]. Interventions aiming to reduce exposure to the virus in the home have been successful $[31,32]$. However, it is not easy to avoid contact with infected individuals, and more needs to be done to support vulnerable people [33]. In particular, vulnerable individuals living in large households may be at risk of exposure to a high viral load from multiple sources if support is not available. In such situations, offering accommodation to vulnerable individuals, with appropriate care and support, could substantially reduce their exposure to the virus.

Participants recognised the significant practical and emotional challenges associated with utilising accommodation to prevent transmission of the virus, and it is critical that those who are in quarantine or isolating outside (and inside) the home are adequately supported. Both practical (e.g., food) and emotional support will be required, for example through community support networks, similar to those that were established at the start of the pandemic. Participants also raised critically important concerns about exposure to infection in 
temporary accommodation that must be addressed. Strategies must be put in place to ensure that those in temporary accommodation are not exposed, or exposing others, to the virus.

There were concerns over who would fund accommodation, and indeed, it would not be cost effective to provide accommodation for all populations. However, we suggest that offering accommodation in a targeted way to those who are vulnerable, exposed to the virus, and/ or unable to quarantine or isolate safely within their home would reduce these costs, and could even lead to a potential reduction in healthcare costs if the number of vulnerable individuals exposed to the virus is reduced.

\section{Limitations}

The main limitation associated with this work is the extent to which the views of our sample are representative of the UK population. Our recruitment for phase one occurred via a mailing list of individuals who had previously used and provided feedback on a website aiming to reduce infection within the home. Our sample comprises predominantly white participants who have completed at least basic education, and are over the age of 40 years. Findings should be interpreted in light of this limitation. This group are likely to be a group of individuals who are highly motivated to engage in infection control behaviours and their views may not be representative of the wider population. Whilst every effort was made to recruit a diverse sample of participants for interviews, our primary use of social media to recruit participants may still have resulted in individuals with certain characteristics being missed. For example, those from non-English speaking communities, those without internet access, and those without social media are unlikely to have been recruited. Despite attempts to recruit participants though existing networks with community group leaders, engagement through these networks was minimal and could not be pursued further due to the need for timely completion of this initial study.

Whilst it is likely that participants recruited to phase 1 of the study have a particular interest in infection control, those who took part in the interview phase of the study had not shown any prior interest in infection control practices. Interestingly, the two populations (phase 1 and 2) presented similar views relating to motivations to engage in infection control behaviour (to keep themselves, their families and their communities safe) and willingness to consider an offer of accommodation in specific circumstances. For example, both phase 1 and phase 2 participants describe a willingness to consider the offer of accommodation if they were unable to isolate within their current home. However, participants with caring responsibilities described greater concerns and challenges that would need to be overcome in order for the option to be feasible. Both groups raised legitimate questions about the location of accommodation and cleanliness of the accommodation, and the facilities and level of support that would be available.

The rapidly changing nature of the pandemic and government advice limits the interpretation of our findings. As perceptions of risk within and outside the home change, the acceptability of accommodation to prevent transmission of the virus in the home may also shift. Our findings must be interpreted with this in mind.

\section{Conclusions}

Within-household transmission is likely to be a leading cause of morbidity and mortality [31] and we present just some of the ways in which accommodation may be viewed and utilised. We recognise the complexities associated with these options, and acknowledge that different households will require very different provisions. The concerns raised by participants must be addressed before such a scheme could be offered. Specific concerns relating to caring duties and responsibilities emphasises the fact that this must be an optional offer made available to those who could benefit, and want to make use of accommodation. However, we suggest that offering accommodation to vulnerable households following a potential exposure to the virus, or during the early stages of an outbreak within the home could be acceptable and feasible.

\section{Abbreviations}

Covid-19: Coronavirus disease 2019; NHS: National Health Service; UK: United Kingdom

\section{Supplementary Information}

The online version contains supplementary material available at https://doi. org/10.1186/s12889-021-11666-z.

\section{Additional file 1.}

Additional file 2 .

\section{Acknowledgements}

Lucy Yardley is an NIHR Senior Investigator and her research programme is partly supported by NIHR Applied Research Collaboration (ARC)-West, NIHR Health Protection Research Unit (HPRU) in Behavioural Science and

Evaluation, and the NIHR Southampton Biomedical Research Centre (BRC). Jeremy Horwood is partly supported by NIHR Applied Research Collaboration (ARC)-West, and NIHR Health Protection Research Unit (HPRU) for Behavioural Science and Evaluation at the University of Bristol. Rachel de Garang is a BME Engagement Worker for the Voice \& Influence Partnership at The Care Forum.

\section{Authors' contributions}

Conceived the study: LY, SD, JH. Study design: LY, SD, JH. Analysed the data: SD, KM, RdG. Interpreted the data: All authors. Drafted the manuscript: SD. Reviewed the manuscript and approved content: All authors. Met authorship criteria: All authors. The author(s) read and approved the final manuscript.

\section{Funding}

This study was funded by the National Institute of Health Research (NIHR) Health Protection Research Unit in Behavioural Science and Evaluation at the 
University of Bristol, in partnership with Public Health England (PHE) and by UK Research and Innovation (UKRI) / Department of Health and Social Care (DHSC) Covid-19 Rapid Response Call 2 (grant number MC_PC 19071). The views expressed are those of the authors and not necessarily those of the NIHR, the Department of Health and Social Care, or PHE. The funders had no role in the design of the study, collection, analysis, and interpretation of the data, or in writing the manuscript.

\section{Availability of data and materials}

The datasets used and/or analysed during the current study are available from the corresponding author on reasonable request.

\section{Declarations}

\section{Ethics approval and consent to participate}

Ethical approval for Phase 1 was provided by Southampton Research Ethics Committee (56445). All survey participants consented online to take part in the study.

Ethical approval for Phase 2 was provided by the NHS Health Research Authority London - Queen Square Research Ethics Committee (20/HRA/ 2549). Due to some participants not having access to printers or other technology required for written/online consent all interview participants verbally consented to take part in the study. Consent statements were read aloud to each participant by the researcher and participants were asked to confirm agreement. The process was audio-recorded and documented by the researcher taking consent. This procedure for obtaining verbal consent was reviewed and approved by the ethics committee.

\section{Consent for publication}

Not applicable.

\section{Competing interests}

None declared.

\section{Author details}

'Population Health Sciences, Bristol Medical School, University of Bristol, Bristol, UK. ${ }^{2}$ School of Psychological Science, University of Bristol, Bristol, UK. ${ }^{3}$ Academic Unit of Psychology, University of Southampton, Southampton, UK. ${ }^{4}$ Public contributor and BME Engagement Worker for the Voice \& Influence Partnership at The Care Forum, Bristol, UK.

\section{Received: 7 September 2020 Accepted: 26 August 2021}

\section{Published online: 08 September 2021}

\section{References}

1. Wilder-Smith A, Freedman M. Isolation, quarantine, social distancing and community containment: pivotal role for old-style public health measures in the novel coronavirus (2019-nCoV) outbreak. J Travel Med. 2020:27(2):1-4.

2. Pan A, Liu L, Wang C. Association of Public Health Interventions with the epidemiology of the COVID-19 outbreak in Wuhan. China JAMA. 2020; 323(19):1915-23. https://doi.org/10.1001/jama.2020.6130.

3. Zhu Y, Wang C, Dong L, Xiao M. Home quarantine or centralised quarantine, which is more conducive to fighting COVID-19 pandemic. Brain Behav Immun. 2020;50889-1591(20):30729-7.

4. Shen M, Peng Z, Guo Y, Rong L, Li Y, Xiao Y, et al. Assessing the effects of metroplitan-wide quarantine on the spread of COVID-19 in public spaces and households. Int J Infect Dis. 2020;S1201-9712:30326-X.

5. Wang Z, Ma W, Zheng X, Wu G, Zhang R. Household transmission of SARSCoV-2. J Infect. 2020;81(1):179-82. https://doi.org/10.1016/j.jinf.2020.03.040.

6. Sjodin H, Wilder-Smith A, Osman S, Farooq Z, Rocklov J. Only strict quarantine measures can curb the coronovirus disease (COVID-19) outbreak in Italy, 2020. Euro Surveill. 2020;25(13):200280.

7. Mao Z, Wan R, He L, Hu Y, Chen W. The enlightenment from two cases of asymptomatic infection from SARS-CoV-2: Is it safe after 14 days of isolation? Int J Infect Dis. 2020;95:174-5.

8. Wang $Y$, Tian H, Zhang L, Zhang M, Guo D, Wu W, et al. Reduction of secondary transmission of SARS-CoV-2 in households by face mask use, disinfection and social distancing: a cohort study in Beijing China. BMJ Glob Health. 2020;5(5):e002794. https://doi.org/10.1136/bmjgh-2020-002794.

9. Atchison C, Bowman L, Vriten C, Redd R, Pristera P, Eaton J, et al. Perceptions and behavioural responses of the general public during the
COVID-19 pandemic: A cross-sectional survey of UK adults. medRxiv. 2020: 04.01.20050039. https://doi.org/10.1101/2020.04.01.20050039.

10. Machida M, Nakamura I, Saito R, Nakaya T, Hanibuchi T, Takamiya T, et al. Adoption of personal protective measures by ordinary citezens during the COVID-19 outbreak in Japan. Int J Infect Dis. 2020;94:139-44.

11. Bodas M, Peleg K. Self-isolation compliance in the COVID-19 era influenced by compensation: findings from a recent survey in Israel. Health Aff. 2020; 39(6):936-41. https://doi.org/10.1377/hlthaff.2020.00382.

12. Yang $M$, Hung $P$, Wu Y, Peng M, Chao $Y$, Su W. A three generation family cluster with COVID-19 infection: Should quarantine be prolonged? Public Health. 2020;50033-3506(20):30205.

13. Chen S, Zhang Z, Yang J, Wang J, Zhai X, Barnighausen T, et al. Fangcang shelter hospitals: a novel concept for responding to public health emergencies. Lancet. 2020;395:1305-14.

14. Public Health England. Understanding the impact of COVID-19 on BAME groups (2020) https://www.gov.uk/government/publications/covid-19understanding-the-impact-on-bame-communities.

15. Niedzwiedz C, O'Donnell C, Jani B, Demou E, Ho F, Celis-Morales C, et al. Ethnic and socioeconomic differences in SARS-CoV-2 infection: prospective cohort study using UK biobank. BMC Med. 2020;18(1):1-14.

16. Pan $D$, Sze S, Minhas J, Bangash M, Pareek N, Divall $P$, et al. The impact of ethnicity on clinical outcomes in COVID-19: A systematic review. EClinicalMedicine. 2020;23:100404.

17. Public Health England. Disparities in the risk of outcomes of COVID-19. 2020. Accessed https://assets.publishing.service.gov.uk/government/uploa ds/system/uploads/attachment_data/file/892085/disparities_review.pdf

18. Razaq A, Harrison D, Karunanithi S, Barr B, Asaria M, Routen A, et al. BAME COVID-19 deaths - what do we know? Rapid data and evidence review. "Hidden in plain sight". 2020. Accessed https://www.cebm.net/covid-19/ba me-covid-19-deaths-what-do-we-know-rapid-data-evidence-review/

19. Bhala N, Currt G, Martineau A, Agyemang C, Bhopal R. Sharpening the global focus on ethnicity and race in the time of COVID-19. Lancet. 2020; 395(10238):1673-6. https://doi.org/10.1016/S0140-6736(20)31102-8.

20. COVID-19 Health System Response Monitor. Cross Country Analysis. How do measures for isolation, quarantine and contract tracing differ among countries? 2020 Available from: https://analysis.covid19healthsystem.org/ index.php/2020/05/19/how-do-measures-for-isolation-quarantine-and-conta ct-tracing-differ-among-countries/.

21. Estrin D, Warner G. "Everybody's getting along here": How Hotel Corona united Israelis and Palestinians. Washington: NPR; 2020. Accessed from https://www.npr.org/2020/06/09/860182244/everybodys-getting-along-herehow-hotel-corona-united-israelis-and-palestinians.

22. Walker V. Need to self-isolate? These hotels are offering "quarantine packages". 2020. Accessed from https://thepointsguy.co.uk/news/hotel-qua rantine-packages-coronavirus/

23. Wira N. Hotels, apartments offer sanctuary for self-isolation. The Jakarta Post 2020. Accessed from https://www.thejakartapost.com/life/2020/04/03/ hotels-apartments-offer-sanctuary-for-self-isolation.html

24. Vaismoradi $\mathrm{M}$, Jones J, Turunen $\mathrm{H}$, Snelgrove S. Theme development in qualitative content analysis and thematic analysis. J Nurs Educ Pract. 2016;6: 100.

25. Vaismoradi M, Turunen $\mathrm{H}$, Bondas T. Content analysis and thematic analysis: implications for conducting a qualitative descriptive study. Nurs Health Sci. 2013;15(3):398-405. https://doi.org/10.1111/nhs.12048.

26. Malterud K, Siersma V, Guassora A. Sample size in qualitative interview studies: guided by information power. Qual Health Res. 2016;26(13):1753-60. https://doi.org/10.1177/1049732315617444.

27. Green J, Thorogood N. Qualitative methods for health research 2nd edition ed: London Sage Publications; 2004.

28. National Health Service. NHS Staff - hotel accomodation. 2020. Accessed from https:/www.england.nhs.uk/coronavirus/wp-content/uploads/sites/ 52/2020/03/hotel-accommodation-for-nhs-staff-20-march-2020.pdf

29. Pujadas E, Chaudhry F, McBride R, Richter F, Zaho S, Wajnberg A, et al. SARS-COV-2 viral load predicts COVID-19 mortality. Lancet Respir Med. 2020; 8(9):e70. https://doi.org/10.1016/S2213-2600(20)30354-4.

30. Xu T, Chen C, Zhu Z. Clinical features and dynamics of viral load in imported and non imported patients with COVID-19. Int J Infect Dis. 2020; 94:68-71 Epub ahead of print

31. Little P, Read R, Amlot R, Chadborn T, Rice C, Bostock J. Reducing risks from coronavirus transmission in the home- the role of viral load. BMJ [Internet]. 2020;269 Available from: https://www.bmj.com/content/369/bmj.m172. 
32. Yardley L, Miller S, Schlotz W, Little P. Evaluation of a web-based intervention to promote hand hygiene: exploratory randomised controlled trial. J Med Internet Res. 2011;13(4):e107.

33. Ainsworth B, Miller S, Denison-Day J, Stuart B, Groot J, Rice C, et al. Current infection control behaviour patterns in the UK, and how they can be improved by "Germ Defence", an online behavioural intervention to reduce the spread of COVID-19 in the home. medRxiv. 2020. https://doi.org/10.11 01/2020.06.22.20137406.

\section{Publisher's Note}

Springer Nature remains neutral with regard to jurisdictional claims in published maps and institutional affiliations.

Ready to submit your research? Choose BMC and benefit from:

- fast, convenient online submission

- thorough peer review by experienced researchers in your field

- rapid publication on acceptance

- support for research data, including large and complex data types

- gold Open Access which fosters wider collaboration and increased citations

- maximum visibility for your research: over $100 \mathrm{M}$ website views per year

At $\mathrm{BMC}$, research is always in progress.

Learn more biomedcentral.com/submissions 